\title{
Biodiesel Synthesis From Coconut Oil using Plug Flow Reactor (PFR)
}

\author{
L.Nurdini, Hendriyana, M.Y.R Anshari , Resti Nadia.P
}

\begin{abstract}
The aim of this research is to determine the properties of biodiesel from coconut oil using plug flow reactor (PFR) using potassium hidroxide (KOH) as catalyst. The experiments were conducted by flowing oil and the catalyst into plug flow reactor continuously. The temperature of reaction at $60^{\circ} \mathrm{C}$, variation of feed flow ( 10 $\mathrm{ml} / \mathrm{min}, 15 \mathrm{ml} / \mathrm{min}, 20 \mathrm{ml} / \mathrm{min}, 25 \mathrm{ml} / \mathrm{min}$ ), methanol ratio $25 \% \mathrm{w} / \mathrm{w}$ oil and catalyst ratio $0,5 \% \mathrm{w} / \mathrm{w}$ oil. The highest biodiesel yield at feed flow rate $25 \mathrm{ml} / \mathrm{min}$ was $86,53 \%$. The density of Biodiesel was $880,04 \mathrm{~kg} / \mathrm{m}^{3}$. The viscosity of biodiesel was 2,8 cSt. The Acid number of biodiesel was $0,228 \mathrm{mgKOH} / \mathrm{g}$. Water content of biodiesel was 7,189\%. Flash point of the biodiesel was $48{ }^{\circ} \mathrm{C}$. From the analysis of biodiesel parameter, the biodiesel was meet the needs of Biodiesel Standard SNI 04-7182-2006 and closed to diesel fuel properties.
\end{abstract}

\section{Keywords : biodiesel, KOH, coconut oil, PFR}

\section{INTRODUCTION}

The energy demand for vehicle fuel in our country is increasing day by day. Majority of Indonesian vehicle fuels are met from fossil fuels. Currently, mandatory use of biodiesel blending in Indonesia is $20 \%$ from diesel oil (B20). In 2025, the target of biodiesel blending increase to B30 [1]. Commonly, Indonesian biodiesel is made from palm oil. Besides palm oil, there are many biomass sources produce vegetable oil as biodiesel raw material that has the potential to be developed. Coconut is one the renewable source produce vegetable oils whose existence is easily available and abundant in Indonesia. It is widely growing tree, especially in coast area of the country. Indonesia is known as one of the largest exporter of coconut oil in the world [2].

Coconut oil like any other vegetable oils and animal fats are triglycerides with free fatty acid composition showed in Table-I, inherently containing glycerine [3]. Coconut oil is converted into biodiesel (metil ester) through the transesterification process (Figure 1). The glycerine removed from biodiesel by gravity separation. In some case, if the coconut oil contains impurities, then a thin layer formed in between the layer of biodiesel and glycerine [3]. Mostly, biodiesel production using simple apparatus equipped with heating mantel, or using Continous Stired

Revised Manuscript Received on January 10, 2020. Universitas Jenderal Achmad Yani.

Dr.Hendriyana, Lecturer, Departement, chemical Engineering Faculty, Universitas Jenderal Achmad Yani.

M.Y.R. Anshari, Student, Deprtement, chemical Engineering, Engineering Faculty, Universitas Jenderal Achmad Yani.
Lulu Nurdini, Lecturer, Departement, chemical Engineering Faculty,

Tank Reactor (CSTR) [4]. In this research, the biodiesel production conducted in plug flow reactor (PFR) with $\mathrm{KOH}$ as catalyst. $\mathrm{KOH}$ catalyst was used in this research because it was more reactive than $\mathrm{NaOH}$ [5]. The reaction of alcoholysis of potassium hidroxide formed potassium methoxide as the catalyst in transesterification process [6].

Table- I: Free Fatty Acid Composition of Coconut Oil [7]

\begin{tabular}{|l|c|}
\hline \multicolumn{1}{|c|}{ Fatty Acid } & $\begin{array}{c}\text { Composition } \\
\text { (\%) }\end{array}$ \\
\hline Hexanoat Acid & 0,0067 \\
\hline Laurate Acid & 7,548 \\
\hline Octanoat Acid & 40,914 \\
\hline Myristate Acid & 22,026 \\
\hline Palmitate Acid & 13,625 \\
\hline Oleat Acid & 9,491 \\
\hline Linoleat Acid & 5,083 \\
\hline Stearat Acid & 0,637 \\
\hline
\end{tabular}

$$
\begin{aligned}
& \mathrm{CH}_{2} \mathrm{COOR}_{1} \quad \mathrm{CH}_{3} \mathrm{CH}_{2} \mathrm{COOR}_{1} \mathrm{CH}_{2} \mathrm{OH} \\
& \mathrm{CHCOOR}_{2}+3 \mathrm{CH}_{3} \mathrm{CH}_{2} \mathrm{OH} \stackrel{\mathrm{KOH}}{\longrightarrow} \mathrm{CH}_{3} \mathrm{CH}_{2} \mathrm{COOR}_{2}+\mathrm{CHOH}
\end{aligned}
$$

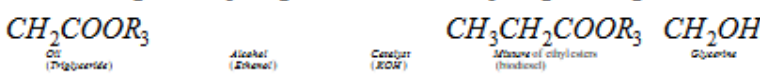

Fig. 1. Transesterification reaction

Things that affecting the transesterification reaction are [8]

- Water and FFA content : the oil must have acid number $<1$

- The ratio of alcohol with the oil : the stoichiometric ratio of oil and methanol is $1: 3$. But bigger ratio of methanol and oil increasing the biodiesel conversion

- Catalyst selection : the appropiate catalyst provide maximum conversion of biodiesel

- Temperature of reaction : the reaction can be carried out at the temperature of $35-60^{\circ} \mathrm{C}$

\section{MATERIALS AND METHODS}

The research experiments conducted in plug flow reactor in the form of a hose pipe along $10 \mathrm{~m}$ and $4 \mathrm{~mm}$ inner diameter of a hose pipe. Figure 2 showed the schematic of the experimental apparatus. The reaction keeped at $60^{\circ} \mathrm{C}$, the catalyst potassium hidroxide concentration ratio $0,5 \% \mathrm{w} / \mathrm{w}$ oil, and methanol ratio $25 \%$ w/w oil. The parameter of biodiesel product compared to SNI 04-7182-2006

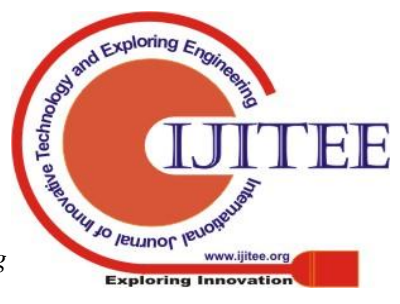


standard for biodiesel and the diesel fuel chacarteristic.

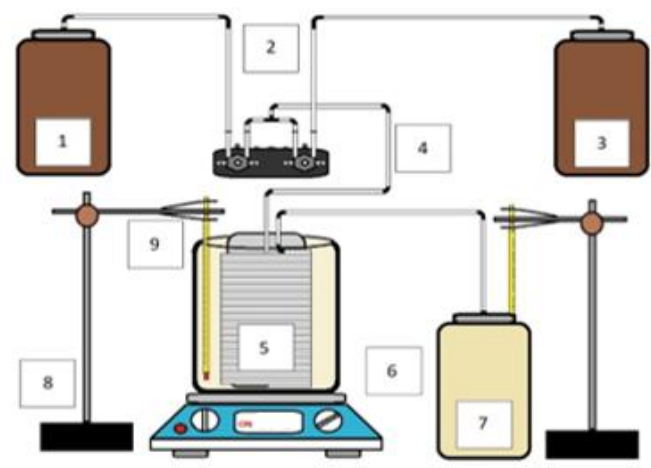

Fig. 2. Schematic apparatus (1) coconut oil tank, (2) pump, (3) catalyst tank, (4) hose pipe, (5) PFR, (6) Hot plate, (7) product, (8) statif, (9) thermometer

\section{RESULT AND DISCUSSION}

The feed flow rate can affect to biodiesel yield. From Figure 3, the higher feed flow rate increased the biodiesel yield. Flow rate in the PFR associated to the intensity of stirring and residence time. So, the reaction run fast. [8]. The higher stirring speed will increased molecular movement and caused a collision [9]. The yield of biodiesel in this experiment is lesser than Saroso work [8]. This is because Saroso using a longer hose pipe as PFR than this experiment. It make the residence time in the plug flow reactor become longer than this experiment and more product of biodiesel produced, becaused the reaction run fast. This also affected to the properties of biodiesel produced in this experiment. The increasing feed flowrate, make the properties of biodiesel value differences each other (Table 2). Increasing metanol ratio in transesterification reaction also make the properties of biodiesel (density, viscosity) decreased compared to the properties of the oil as a raw material the biodiesel [10].

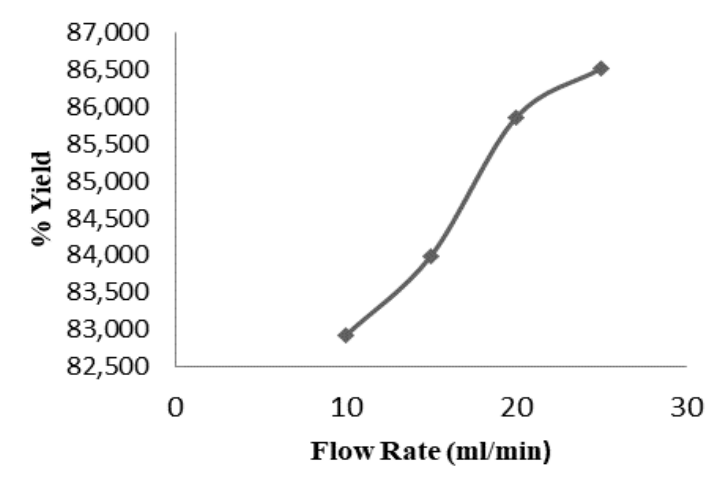

\section{Fig. 3. Feed Flow Rate vs Biodiesel Yield}

The value of biodiesel density showed in Figure 4 has decreased with increasing feed flow rate. If we compared to the density value of coconut oil $0,908-0,921 \mathrm{~kg} / \mathrm{m}^{3}$ [10], the biodiesel density decreased and meet the SNI 04-7182-2006 and diesel fuel characteristic. Transeseterification reaction can reduce the density by decreasing the length of carbon chain and increased skeletal bonding [11]. If the biodiesel density is greater than the standard of biodiesel, it will caused engine damage due to increased in engine wear and high emissions [12].

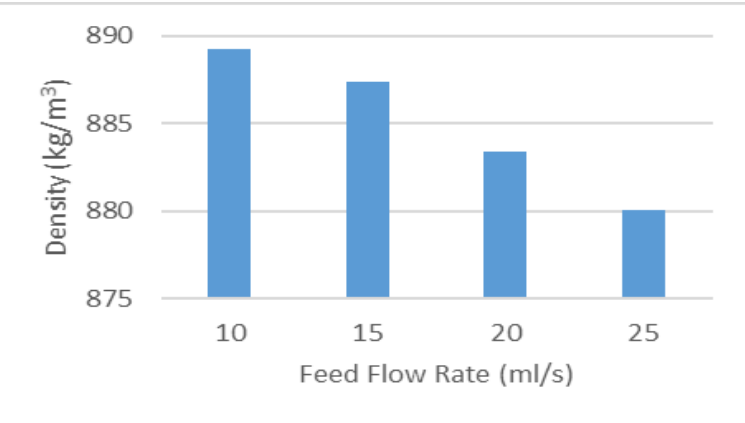

Fig. 4. Density of Biodiesel vs Feed Flow Rate (ml/s)

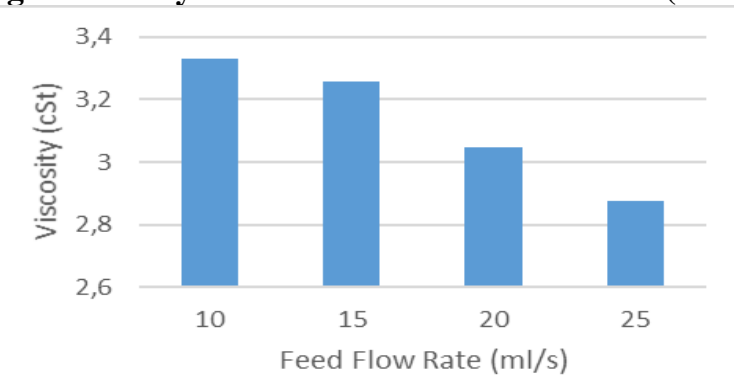

Fig. 5. Viscosity of Biodiesel vs Feed Flow Rate (ml/s)

The biodiesel viscosity also decreased when feed flow rate increase as shown in Figure 5. Transesterification reaction causes a decrease in triglicerides viscosity. This is due to the reducing molecular weight of triglicerides converted to methyl ester [13]. Viscosity becomes the main parameter $\mathrm{n}$ determning the quality of biodiesel, because has a big influence on the effectiveness of biodiesel as fuel. Higher viscosity of biodiesel causing atomized fuel into bigger droplet and it caused a problem in engine performance and make injection pump work harder to make the oil flowing [14].

The acid number also an important parameter show the effectiveness of transesterification reaction. When the acid number decrease in biodiesel, it is indicate the reaction produced methyl ester as biodiesel. The catalyst has an important role in the reaction process [15]. When the catalyst ratio increase, methyl ester in the product also increased, and the acid number would be decreased as shown in Figure 6. It is because the free fatty acid in the oil converted into methyl ester. But if the use of catalyst is excessive, the biodiesel yield decreased [11]. It caused saponification reaction and produce an emulsion, and the transesterification reaction cannot occured.

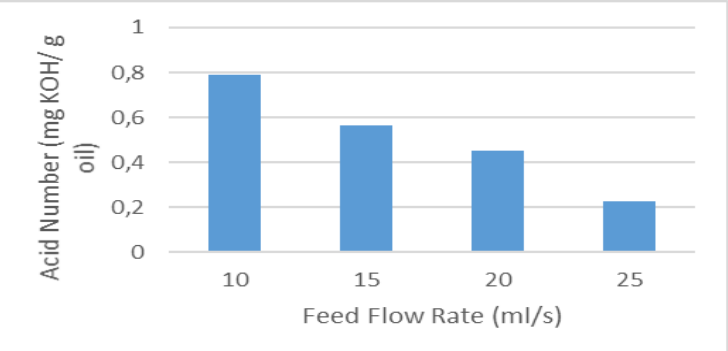

Fig. 6. Acid Number of Biodiesel vs Feed Flow Rate (ml/s) 
Table-II shows the characteristic of biodiesel compared to SNI biodiesel standard and diesel fuel characteristic. The water content and flash point of the biodiesel do not meet the biodiesel standard and diesel fuel characteristic. The water content in biodiesel higher than the standard. It is because the catalyst is hygroscopic, if it exposed into the air it will cause a high water content . The flash point biodiesel lower than biodiesel standard and diesel standard. The biodiesel flash point has a higher than the diesel fuel flash point. The differences is related to the components present in each fuel [16]. The density, viscosity and acid number in biodiesel (Table II) meet the needs of SNI biodiesel standard and diesel fuel characteristic.

\section{CONCLUSION}

Biodiesel product having density of Biodiesel was $880,04 \mathrm{~kg} / \mathrm{m}^{3}-889,24 \mathrm{~kg} / \mathrm{m}^{3}$. The viscosity of biodiesel was $2,8-3,3 \mathrm{cS}$. The Acid number of biodiesel was 0,228 $-0,789 \mathrm{mgKOH} / \mathrm{g}$. Water content of biodiesel was 7,189 $-7,981 \%$. Flash point of the biodiesel was $34-48{ }^{\circ} \mathrm{C}$. From the analysis of biodiesel parameter, the biodiesel was meet the needs of SNI 04-7182-2006 biodiesel standard and diesel properties.

Table- II: The analysis of Biodiesel Parameter

\begin{tabular}{|c|c|c|c|c|c|c|c|}
\hline \multirow{2}{*}{ No } & \multirow{2}{*}{ Biodiesel Parameter } & \multicolumn{4}{|c|}{ Flow Rate $(\mathrm{ml} / \mathrm{s})$} & \multirow{2}{*}{ SNI 04-7182-2006 } & \multirow{2}{*}{ Diesel Fuel } \\
\hline & & 10 & 15 & 20 & 25 & & \\
\hline 1 & Density $\left(\mathrm{kg} / \mathrm{m}^{3}\right)$ & 889,24 & 887,36 & 883,4 & 880,04 & $850-890$ & $815-870$ \\
\hline 2 & Viscosity (cSt) & 3,331 & 3,256 & 3,049 & 2,876 & $2,3-6,0$ & $2,0-5,0$ \\
\hline 3 & $\begin{array}{l}\text { Acid Number } \\
\text { (mg KOH/g oil) }\end{array}$ & 0,789 & 0,564 & 0,454 & 0,228 & $\max .0,8$ & $\max .0,6$ \\
\hline 4 & Water Content (\%) & 7,981 & 7,728 & 7,189 & 7,277 & $\max .0,05$ & $\begin{array}{c}\max .500 \\
(\mathrm{mg} / \mathrm{kg})\end{array}$ \\
\hline 5 & Flash Point $\left({ }^{0} \mathrm{C}\right)$ & 37 & 34 & 45 & 48 & $\begin{array}{l}\text { min. } 100 \text { (closed } \\
\text { container) }\end{array}$ & $\min .52$ \\
\hline
\end{tabular}

\section{ACKNOWLEDGMENT}

This research was funded by LPPM Universitas Jenderal Achmad Yani (UNJANI).

\section{REFERENCES}

1. Tim Riset PASPI., (2017) https://gapki.id/news/3024/perkembangan-mandatori-biodiesel-dan-pros pek-indonesia-dalam-pasar-biodiesel-dunia, Accessed in 31 July 2019.

2. Sukmaya, Syahrul Ganda., (2017). Analysis of Indonesian Coconut Crude oil in the International Market. AGRARIS : Journal of Agribusiness and Rural Development Research, 3, 1.

3. ALAMU, Oguntola J., DEHINBO, Opeoluwa., SULAIMAN, Adedoyin M., (2010). Production and Testing of Coconut Oil Biodiesel Fuel and its Blend, Leonardo Journal of Science, 16, 95-104.

4. Aziz, Isalmi., (2008). Biodiesel production from cooking oil waste using stirred tank reactor, VALENSI, $1,2$.

5. Astuti, Erna. (2009). Biodiesel production from coconut oil and ethanol with $\mathrm{KOH}$ catalyst. Jurnal Teknik Gelagar, 20, 01.

6. Hendriyana, Herri Susanto, Subagjo. Thermodynamics and kinetics study of $\mathrm{CH}_{3} \mathrm{OK}$ preparationfrom $\mathrm{KOH}$ and $\mathrm{CH}_{3} \mathrm{OH}$, ARPN Journal of Engineering and Applied Sciences, 11, 16, 9946-9950.

7. Hidayanti, Nur, et al., (2015). Biodiesel production from coconut oil with base catalyst through the transesterification process using microwaves, Jurnal Teknik Kimia, 10, 1.

8. Saroso, H., (2006). Study on reaction kinetics transesterification coconut oil by using the catalyst $\mathrm{NaOH}$ plug flow reactor, International Journal of Engineering Innovation and Research, 5, 3 .

9. Mas'udah, et al., (2010). Biodiesel production using plug flow reactor (PFR) continuously, Departement of Chemical Engineering. State Polytechnic of Malang.

10. L. Nurdini, Hendriyana, B.K.Muttaqin, H. Hermawan., (2019). Characterization of biodiesel from Bauhinia purpurea L seeds, Seminar on research and community service results, Unjani Expo (UNEX) I. Cimahi.

11. Mahlida, M., Busthan, Meuthia., (2017). In situ transesterification of Aluerites moluccana L using recycled methanol using ultrasonic wave, AGRITECH, 37, 3, 295-301.

12. Syah, A.N. A., (2005). Virgin coconut oil : conqueror oils of various diseases, Agro Media.

13. Setiorini, I., Zuhri, A.A., (2010). Solid density in continuous form and liquid, Laporan Seminar Fisika Jurusan Fisika. Universitas Negeri Surabaya.

14. Nurdiansyah and A. Redha., (2011). Effects of copra powder maceration time on yield, density, and biodiesel acid number resulting from in situ transesterification method, Jurnal Belian. 10, 2, 218-224.

15. D. Hendra, S. Wibowo, N. Hastuti and H. S. Wibisono., (2016). Characteristic of biodiesel bintaro seeds (Cerbera manghas L) with the modification process, Jurnal Penelitian Hasil Hutan, 34, 1,11-21.

16. Fernandez, Cristina Gonzalez., Munoz, Raul., (2018), Microalgae based biofuels an bioproducts from feedstock cultivation to end products, 560, Woodhead Publshing.
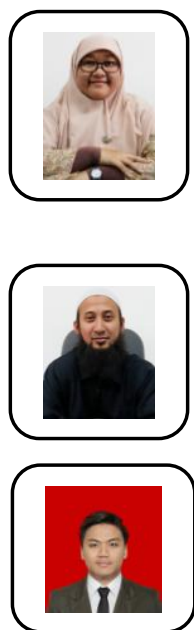

\section{AUTHORS PROFILE}

Lulu Nurdini, ST., MT, is a researcher and lecturer in chemical departement, Engineering Faculty, Universitas Jenderal Achmad Yani. Master of Engineering, Institut Teknologi Bandung, 2015. Currently works in enviromental issue and biomass conversion.

Dr.Hendriyana, is a researcher and lecturer in chemical departement, Engineering Faculty, Universitas Jendera Achmad Yani. Doctoral degree, Institut Teknologi Bandung, 2016. Currently works in biomass conversion.

M.Y.R. Anshari, is a chemical engineering deprtement student, Engineering Faculty, Universitas Jenderal Achmad Yani. 